\title{
Pengaruh Waktu Ekstraksi, Rasio Bahan/Pelarut, dan Daya Microwave Terhadap Hasil Ekstraksi Minyak Serai Dapur dengan Bantuan Gelombang Mikro
}

\author{
Effect of Extraction Time, Ingredient/Solvent Ratio, and Microwave Power on Extraction \\ Results of Lemongrass Oil with Microwave Assistance
}

\author{
Venitalitya A. S. Augustia*, Naufal Charfadz, Rizki Akbar, Diana \\ Program Studi Teknik Kimia, Fakultas Teknologi Industri, Universitas Islam Indonesia, Jalan Kaliurang KM \\ 14,5, Umbulmartani, Ngemplak, Kab. Sleman, 55584, Indonesia \\ *Email: venitalitya.augustia@uii.ac.id
}

\begin{abstract}
Abstrak
Serai dapur merupakan sumber minyak atsiri yang banyak tumbuh di Indonesia. Beberapa metode untuk mengekstrak minyak atsiri, antara lain metode hidrodistilasi, distilasi kukus, ekstraksi soxhlet, ekstraksi dengan fluida superkritis, ekstraksi dengan ultrasonik, dan ekstraksi dengan gelombang mikro. Pada penelitian ini, metode ekstraksi yang digunakan adalah hidrodistilasi dengan bantuan gelombang mikro. Tujuan dari penelitian ini adalah untuk mengetahui pengaruh waktu ekstraksi (60 menit, 75 menit, dan 90 menit), rasio bahan/pelarut ( $1: 4 \mathrm{~g} / \mathrm{mL}$ dan $1: 5 \mathrm{~g} / \mathrm{mL})$, dan daya (500 watt dan 600 watt) terhadap kuantitas dan kualitas ekstrak minyak atsiri serai dapur. Hasil minyak atsiri yang diperoleh dilakukan analisis berupa perhitungan densitas minyak atsiri, yield, dan analisis GC-MS. Hasil analisis menunjukkan bahwa densitas minyak serai dapur hasil ekstraksi berkisar antara $0,880 \mathrm{~g} / \mathrm{mL}-0,920$ $\mathrm{g} / \mathrm{mL}$ pada suhu $30^{\circ} \mathrm{C}$, dengan yield tertinggi berkisar antara $0,0044 \%-0,0046 \%$ pada sampel dengan rasio bahan/pelarut 1:5 $\mathrm{g} / \mathrm{mL}$. Komponen minyak serai dapur yang diperoleh terdiri dari beberapa senyawa, yaitu Z-citral, geranil asetat, dan geraniol.
\end{abstract}

Kata kunci: daya, gelombang mikro, serai dapur, waktu ekstraksi, rasio bahan dan solven

\begin{abstract}
Lemongrass, one type of source of essential oils, is widely cultivated in Indonesia. There are several methods for extracting the essential oils from lemongrasses, such as hydro-distillation, steam distillation, soxhlet extraction, extraction with supercritical fluids, ultrasonic extraction, and microwave-assisted hydro-distillation. In this study, microwave-assisted hydro-distillation was used as the extraction method. The purpose of this study was to determine the effect of extraction time (60 minutes, 75 minutes, and 90 minutes), lemongrass/solvent ratio $(1: 4 \mathrm{~g} / \mathrm{mL}$ and 1:5 g/mL), and microwave power (500 watt and 600 watt) on quantity and quality of lemongrass essential oil. The essential oils obtained were analyzed in the form of calculation of the essential oil density, yield, and GC-MS analysis. The results of the analysis showed that the density of the extracted lemongrass oil ranged from $0.880 \mathrm{~g} / \mathrm{mL}-0.920 \mathrm{~g} / \mathrm{mL}$ at a temperature of $30{ }^{\circ} \mathrm{C}$, with the highest yield ranging from $0.0044 \%-0.0046 \%$ in samples with a material/solvent ratio of $1: 5 \mathrm{~g} / \mathrm{mL}$. The components found in lemongrass oil were Z-citral, geranyl acetate, geraniol.
\end{abstract}

Keywords: power, microwave, lemongrass, extraction time, raw material and solvent ratio

\section{Pendahuluan}

Minyak atsiri merupakan senyawa yang dapat ditemukan secara alami pada berbagai jenis tanaman aromatik. Bagian tanaman yang mengandung minyak atsiri adalah seperti daun, bunga, kecambah, biji, dan juga pucuknya. Beberapa contoh tanaman yang digunakan sebagai sumber bahan baku minyak atsiri adalah serai, jeruk, mawar, dan cengkeh. Komponen yang terkandung dalam minyak atsiri merupakan campuran senyawa volatil, menghasilkan suatu aroma khas, memiliki berat molekul yang rendah, serta memiliki sifat hidrofobik [1].

Terdapat kandungan minyak atsiri yang dapat mencegah pertumbuhan berbagai jenis mikroorganisme [2]. Senyawa bioaktif yang terkandung dalam minyak atsiri memiliki sifat antimikroba dan antioksidan yang sangat baik jika digunakan pada bidang kosmetik, farmasi, dan juga makanan. Kedua sifat ini memiliki peran yang penting untuk mencegah terjadinya kerusakan pada makanan 
dan juga sebagai bahan pengawet alami pada makanan [3].

Salah satu sumber minyak atsiri yang banyak tumbuh di Indonesia adalah serai dapur. Tanaman ini memiliki nama latin berupa Cymbopogon citratus dan Cymbopogon flexuosus. Minyak atsiri yang dihasilkan mengandung kandungan senyawa sitral pada serai tersebut. Selain itu, serai dapur juga mengandung senyawa lain, seperti geraniol dan geranial [4].

Terdapat beberapa metode untuk mengekstrak minyak atsiri pada serai dapur, antara lain metode hidrodistilasi, distilasi kukus, ekstraksi soxhlet, ekstraksi dengan fluida superkritis, ekstraksi dengan ultrasonik, dan ekstraksi dengan gelombang mikro. Metode ekstraksi dengan bantuan gelombang mikro memiliki kelebihan dari sisi waktu ekstraksi yang lebih singkat dan konsumsi energi yang lebih sedikit [5].

Pada penelitian ini, metode ekstraksi yang digunakan adalah hidrodistilasi dengan bantuan gelombang mikro. Hidrodistilasi merupakan ekstraksi dengan pelarut berupa air. Metode ini merupakan metode konvensional yang sering digunakan untuk mengekstrak minyak atsiri dari berbagai tanaman, khususnya pada industri farmasi [6]. Konsumsi energinya yang cukup tinggi dan waktu ekstraksi yang cukup lama, maka digunakan gelombang mikro untuk meningkatkan yield ekstraksi, mempersingkat waktu ekstraksi, dan menurunkan biaya operasional [6].

Tujuan dari penelitian ini adalah untuk mengetahui pengaruh waktu ekstraksi (60 menit, 75 menit, dan 90 menit), rasio serai dapur/pelarut air (1:4 $\mathrm{g} / \mathrm{mL}$ dan $1: 5 \mathrm{~g} / \mathrm{mL}$ ), dan daya gelombang mikro (500 watt dan 600 watt) terhadap kuantitas dan kualitas minyak atsiri serai dapur yang dihasilkan. Hasil minyak atsiri yang diperoleh dilakukan analisis berupa perhitungan densitas minyak atsiri, yield, dan analisis komponen minyak atsiri menggunakan GCMS.

\section{Teori}

Serai dapur atau yang memiliki nama latin Cymbopogon citratus, merupakan salah satu jenis serai yang mudah ditemui di Afrika, Amerika, dan Asia, seperti Indonesia dan Malaysia. Serai ini umum digunakan sebagai bahan masakan pada beragam jenis masakan Nusantara. Serai dapur memiliki aroma seperti lemon, bentuk seperti rumput dengan ukuran yang tinggi yang dapat mencapai ukuran $1 \mathrm{~m}$, dan lebar daun berkisar antara 5-10 mm. [7]. Tanaman ini cukup mudah untuk dibudidayakan khususnya di daerah dengan iklim tropis dan pada ketinggian 1200 mdpl [7].

Pada serai dapur ditemukan beberapa senyawa kimia, seperti tanin, terpenoid, fenol, flavonoid, dan gula [7-9]. Senyawa tersebut diisolasi dengan cara proses ekstraksi minyak atsiri dari tanaman serai dapur. Kandungan minyak atsiri pada serai dapur berkisar antara $1-2 \%$ dalam basis kering [9]. Beragam kandungan yang dimiliki oleh serai dapur menyebabkan minyak atsiri yang dihasilkan bermanfaat sebagai bahan baku parfum, antipasmodik, analgesik, anti-inflamasi, dan antioksidan [7] [10].

Minyak atsiri dapat diperoleh melalui proses ekstraksi tanaman serai dapur. Beragam metode ekstraksi yang dapat digunakan, seperti distilasi fraksional, distilasi kukus, hidrodistilasi, dan soxhlet [10]. Pengembangan dari metode hidrodistilasi, yaitu ekstraksi menggunakan microwave [11]. Metode ini memberikan yield yang lebih tinggi, kebutuhan energi yang lebih rendah, dan waktu ekstraksi yang lebih singkat dibandingkan dengan metode ekstraksi konvensional [11].

Kualitas dan kuantitas produk minyak atsiri hasil dari proses ekstraksi dengan microwave dipengaruhi oleh berbagai parameter. Contoh parameter tersebut, yaitu waktu ekstraksi, jumlah massa bahan baku, kondisi bahan baku, ukuran bahan baku, volume pelarut, jenis pelarut, dan daya microwave. Waktu ekstraksi merupakan faktor yang sanagt krusial. Semakin besar waktu ekstraksi maka yield akan semakin besar [11]. Besaran jumlah massa bahan dan volume pelarut dapat bisa dituliskan dalam rasio bahan/pelarut. Semakin kecil rasio tersebut maka minyak atsiri dapat diisolasi secara optimal karena level densitas bahan yang yang tidak terlalu tinggi [11]. Daya microwave menjadi salah satu yang dipertimbangkan karena semakin tinggi daya ekstraksi akan menghasilkan energi dan suhu yang lebih besar pula sehingga proses pemanasan akan lebih cepat [11].

\section{Metodologi Penelitian}

\section{Bahan dan Alat}

Bahan utama yang digunakan pada penelitian ini adalah tanaman serai dapur dalam keadaan segar dan aquadest. Alat ekstraksi utama yang digunakan adalah oven microwave yang dimodifikasi.

\section{Cara Kerja}

Proses ekstraksi minyak atsiri dari serai dapur dilakukan dengan metode ekstraksi dengan gelombang mikro. Cara kerja proses ekstraksi dengan gelombang mikro yang diadaptasi dari penelitian yang dilakukan oleh Chenni et al. (2020) dengan modifikasi adalah (i) menyiapkan alat oven microwave yang telah dimodifikasi untuk proses ekstraksi, (ii) memotong batang serai segar dan memasukan ke dalam tabung sampel yang mengandung aquadest dengan berbagai rasio serai dapur/pelarut (1:4 g/mL dan 1:5 g/mL), (iii) melakukan ekstraksi pada berbagai waktu ekstraksi (60 menit, 75 menit, dan 90 menit) dan pada berbagai daya oven microwave (500 watt dan 600 watt), dan (iv) mengeringkan minyak atsiri hasil dari proses ekstraksi, lalu menimbangnya, dan menyimpan pada suhu $4{ }^{\circ} \mathrm{C}$ sebelum dilakukan proses analisis [12]. Pada Tabel 1 dapat dilihat detail sampel ekstrak minyak atsiri dari serai dapur yang digunakan pada penelitian ini. 
Tabel 2. Detail sampel ekstrak minyak atsiri dari serai dapur

\begin{tabular}{|c|c|c|c|c|}
\hline \multirow{2}{*}{ No. } & \multirow{2}{*}{$\begin{array}{c}\text { Nama } \\
\text { Sampel }\end{array}$} & \multicolumn{3}{|c|}{ Keterangan } \\
\cline { 3 - 5 } & $\begin{array}{c}\text { Waktu } \\
\text { Ekstraksi } \\
\text { (menit) }\end{array}$ & $\begin{array}{c}\text { Rasio } \\
\text { Bahan/Pelarut } \\
(\mathrm{g} / \mathrm{mL})\end{array}$ & $\begin{array}{c}\text { Daya } \\
\text { Ekstraksi } \\
\text { (watt) }\end{array}$ \\
\hline 1 & RD451 & 60 & $1: 4$ & 500 \\
\hline 2 & RD452 & 75 & $1: 4$ & 500 \\
\hline 3 & RD453 & 90 & $1: 4$ & 500 \\
\hline 4 & RD554 & 60 & $1: 5$ & 500 \\
\hline 5 & RD555 & 75 & $1: 5$ & 500 \\
\hline 6 & RD556 & 90 & $1: 5$ & 500 \\
\hline 7 & RD461 & 60 & $1: 4$ & 600 \\
\hline 8 & RD462 & 75 & $1: 4$ & 600 \\
\hline 9 & RD463 & 90 & $1: 4$ & 600 \\
\hline 10 & RD564 & 60 & $1: 5$ & 600 \\
\hline 11 & RD565 & 75 & $1: 5$ & 600 \\
\hline 12 & RD566 & 90 & $1: 5$ & 600 \\
\hline
\end{tabular}

*)Keterangan:

RD45i: sampel dengan variasi berbagai waktu ekstraksi pada rasio konstan 1:4 $\mathrm{g} / \mathrm{mL}$ daya konstan pada 500 watt.

RD55i: sampel dengan variasi berbagai waktu ekstraksi pada rasio konstan 1:5 g/mL daya konstan pada 500 watt.

RD46i: sampel dengan variasi berbagai waktu ekstraksi pada rasio konstan 1:4 g/mL daya konstan pada 600 watt.
RD56i: sampel dengan variasi berbagai waktu ekstraksi pada rasio konstan 1:5 g/mL daya konstan pada 600 watt.

$\mathrm{R}$ menunjukkan rasio bahan/pelarut konstan dan $\mathrm{D}$ menunjukkan daya ekstraksi konstan.

\section{Analisis Hasil Ekstraksi}

Terdapat tiga analisis yang dilakukan pada penelitian ini, yaitu (i) analisis densitas minyak atsiri, (ii) analisis yield, dan (iii) analisis komponen minyak atsiri menggunakan Gas Chromatography-Mass Spectrometry (GC-MS). Ketiga analisis ini digunakan untuk mengetahui kualitas dan kuantitas sampel minyak atsiri yang diperoleh. Terdapat dua belas sampel dengan keterangan seperti tercantum pada 2.

\section{Hasil}

Pengaruh Waktu Ekstraksi, Rasio Bahan/Pelarut, dan Daya Terhadap Densitas Minyak Atsiri

Salah satu spesifikasi persyaratan mutu suatu minyak serai dapur berdasarkan Standar Nasional Indonesia SNI 06-3953-1995 BSN, yaitu densitas. Nilai densitas yang dipersyaratkan adalah berkisar antara $0,8731 \mathrm{~g} / \mathrm{cm}^{3}-0,8902 \mathrm{~g} / \mathrm{cm}^{3}$ [13]. Pada Gambar 1 terlihat bahwa nilai densitas pada berbagai sampel telah memenuhi persyaratan tersebut. Nilai densitas pada penelitian ini berkisar antara 0,880 $\mathrm{g} / \mathrm{mL}-0,920 \mathrm{~g} / \mathrm{mL}$ pada suhu $30{ }^{\circ} \mathrm{C}$. Hal ini dapat disimpulkan bahwa adanya perbedaan variasi pada waktu ekstraksi, rasio bahan/pelarut, serta daya ekstraksi tidak memberikan pengaruh yang signifikan terhadap nilai densitas pada minyak atsiri yang dihasilkan.

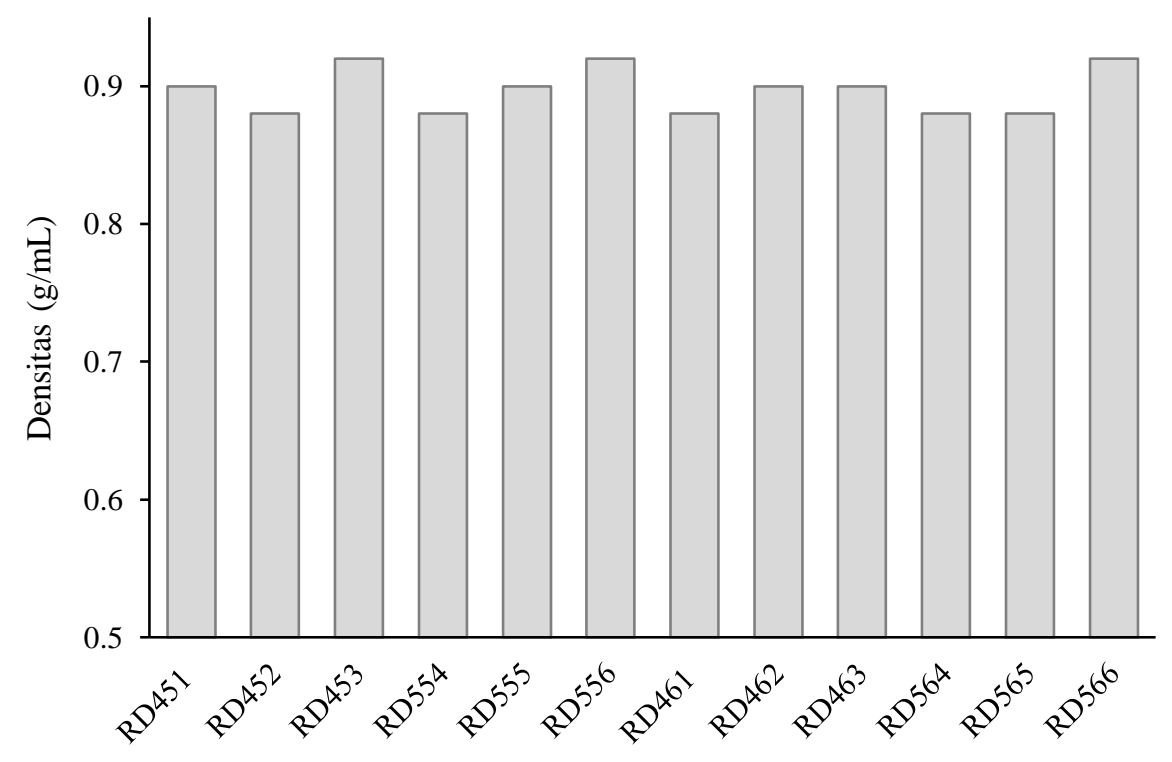

Gambar 1. Nilai densitas minyak serai dapur pada berbagai sampel

Pada dasarnya densitas minyak atsiri dipengaruhi oleh komponen-komponen yang menyusun minyak atsiri tersebut. Semakin panjang rantai penyusun minyak atsiri dan semakin besar berat 
molekulnya, maka densitas minyak atsiri akan semakin besar [13]. Selain itu, semakin lama proses ekstraksi yang dilakukan maka akan semakin banyak senyawa yang dapat diekstraksi sehingga akan meningkatkan konsentrasi minyak atsiri dan juga densitasnya [13]. Namun, pada penelitian ini, perbedaan waktu ekstraksi tidak terlalu signifikan. Oleh karena itu, densitas yang dihasilkan seragam atau tidak memiliki perbedaan yang terlalu jauh. Hal ini ditunjukkan pada Gambar 1. Pada rasio bahan/pelarut dan daya ekstraksi yang sama, nilai densitas minyak atsiri tertinggi, yaitu pada waktu ekstraksi terpanjang (90 menit). Pada penelitian yang dilakukan oleh peneliti lain, nilai densitas minyak serai dapur yang diperoleh dengan metode distilasi adalah $0,8796 \mathrm{~g} / \mathrm{cm}^{3}$ pada suhu $25{ }^{\circ} \mathrm{C}$ [14]. Nilai densitas ini merupakan nilai yang paling baik yang diperoleh pada penelitian tersebut.

\section{Pengaruh Waktu Ekstraksi, Rasio Bahan/Pelarut, dan Daya Terhadap Yield Minyak Atsiri}

Liu et al. (2011) menyatakan bahwa rasio bahan/pelarut merupakan salah satu faktor penting dalam suatu optimasi yield ekstraksi [15]. Berdasarkan grafik pada Gambar 2, pada daya dan waktu ekstraksi yang sama, nilai yield pada rasio bahan/pelarut 1:5 g/mL memberikan hasil yang lebih besar dibandingkan dengan yield 1:4 g/mL. Hal ini bisa terlihat pada contoh sampel RD451 dan RD454 serta RD461 dan RD464. Penggunaan pelarut yang terlalu banyak menyebabkan proses ekstraksi menjadi cukup sulit, namun jika jumlah pelarut terlalu sedikit maka hasil ekstrak yang dihasilkan juga kurang optimal [15]. Pada penelitian ini, rasio bahan/pelarut yang lebih besar memberikan yield yang lebih besar. Hal ini dikarenakan jumlah pelarut yang digunakan masih dalam jumlah yang optimal untuk proses ekstraksi. Namun sebaliknya, pada rasio 1:4 g/mL, nilai yield lebih rendah dikarenakan proses eksraksi yang belum optimal. Air, sebagai pelarut yang digunakan pada penelitian ini, merupakan media untuk melarutkan komponen-komponen yang terkandung pada serai tersebut. Dengan jumlah yang sedikit, maka kapasitas pelarutannya pun akan menurun sehingga jumlah minyak atsiri yang terekstraksi akan sedikit [16].

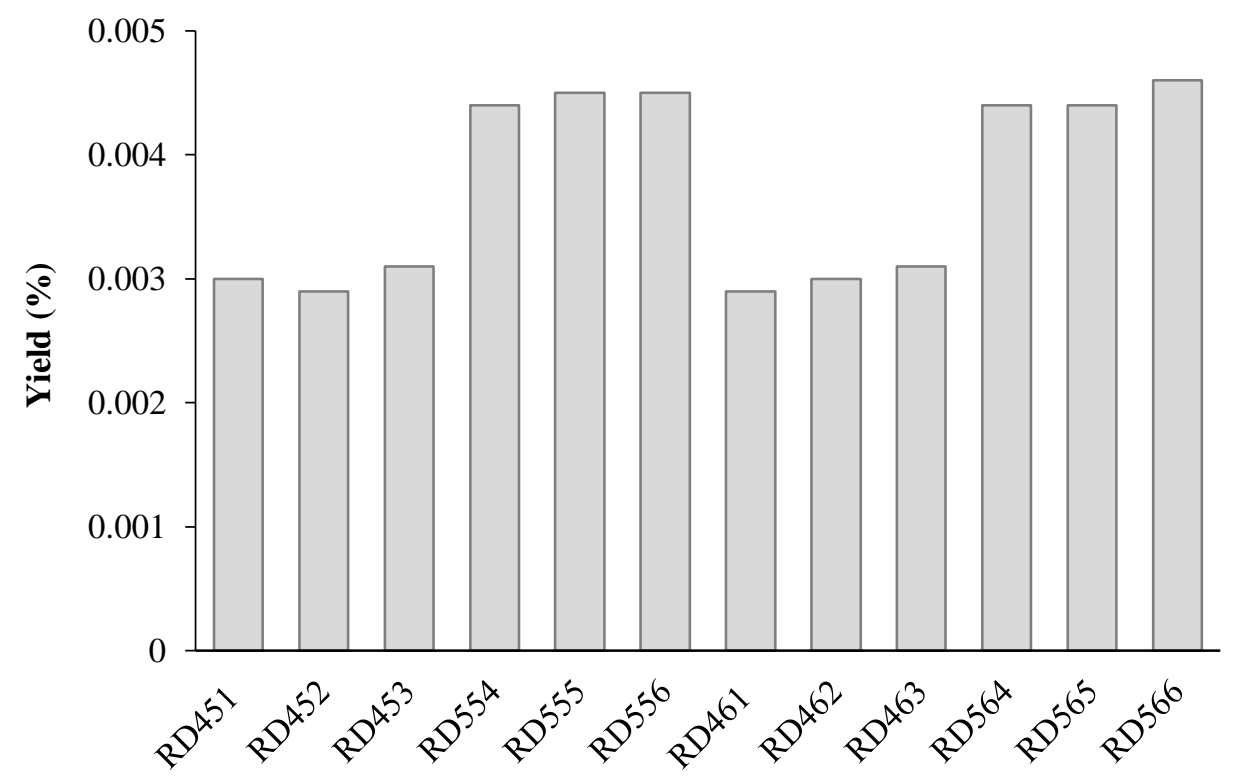

Gambar 2. Nilai yield minyak serai dapur pada berbagai sampel

Selain rasio bahan baku dan pelarut, waktu ekstraksi juga menjadi salah satu yang krusial dalam suatu proses ekstraksi. Berdasarkan Gambar 2 dan Gambar 3, yield ekstraksi pada daya dan rasio bahan/pelarut yang sama, menunjukkan nilai yang hampir seragam. Hal ini menunjukkan bahwa tidak adanya pengaruh perbedaan waktu estraksi yang cukup signifikan setelah 60 menit ekstraksi dijalankan. Hal ini dimungkinkan karena kondisi yang telah jenuh dimana hampir semua minyak atsiri sudah terekstrak secara optimal. Pada penelitian yang dilakukan oleh Drinic et al. (2020), menunjukkan bahwa proses ekstraksi minyak atsiri menggunakan metode yang sama hanya membutuhkan waktu selama 24 menit untuk daya sebesar 600 watt [17]. Pada umumnya, ekstraksi minyak atsiri menggunakan hidrodistilasi dengan bantuan gelombang mikro akan membutuhkan waktu lebih singkat dibandingkan dengan metode hidrodistilasi konvensional. Metode hidrodistilasi membutuhkan waktu 112 menit lebih banyak dibandingkan dengan metode hidrodistilasi dengan gelombang mikro menggunakan 600 watt [17]. Hal ini disebabkan oleh adanya perbedaan teknik pemanasan yang terjadi pada kedua metode tersebut [17].

Selain rasio bahan/pelarut dan waktu ekstraksi, nilai yield juga dipengaruhi oleh adanya perbedaan daya gelombang mikro yang digunakan. Pada penelitian ini menggunakan dua variasi daya, yaitu 500 watt dan 600 watt. Berdasarkan data pada Gambar 
2 dapat dilihat bahwa pada waktu ekstraksi dan rasio bahan/pelarut yang sama, nilai yield ekstraksi hampir sama. Pada dasarnya, pada keadaan proses yang sama, semakin rendah daya yang digunakan maka akan menghasilkan nilai yield yang lebih rendah. Hal ini terjadi karena pemanasan yang belum optimal sehingga menyebabkan minyak atsiri yang terkekstrak belum optimal. Chen dan Spiro (1995) menyebutkan bahwa dengan daya yang tinggi maka sinar microwave akan terabsorp lebih banyak oleh air sehingga dapat menyebabkan merusak struktur sel dari tanaman atau bahan baku minyak atsiri [18]. Hasil penelitian ini menunjukkan tidak adanya perbedaan nilai yield yang signifikan pada penggunaan daya 500 watt dan 600 watt. Hal ini dikarenakan oleh karena perbedaan daya yang tidak terlampau jauh sehingga menghasilkan nilai yield yang hampir sama pula.

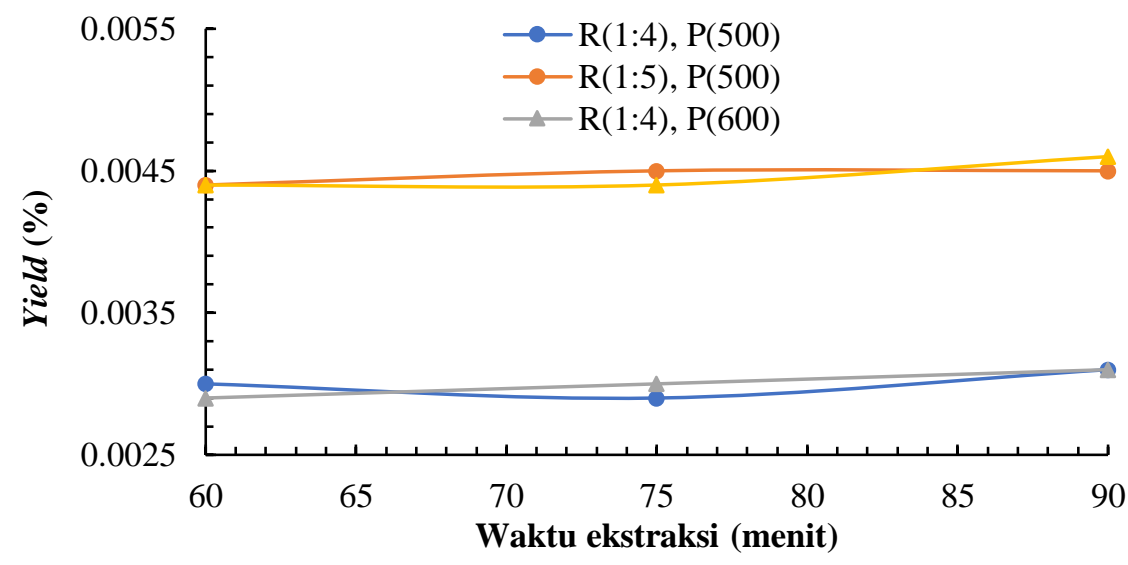

Gambar 3. Pengaruh waktu ekstraksi terhadap yield minyak serai dapur

Tabel 3. Komposisi kimia minyak serai dapur sampel RD451 dengan metode ekstraksi dengan gelombang mikro

\begin{tabular}{|c|c|c|c|}
\hline No. & Nama Senyawa & $\begin{array}{l}\text { Waktu } \\
\text { Retensi } \\
\text { (Menit) }\end{array}$ & $\begin{array}{l}\text { Persen Area } \\
\quad(\%)\end{array}$ \\
\hline 1 & Trans-2-Cis-6-Nonadienal & 13,358 & 0,31 \\
\hline 2 & Longipinenepoxide & 14,007 & 0,31 \\
\hline 3 & 3-Undecyne & 14,605 & 0,59 \\
\hline 4 & Z-Citral & 17,916 & 59,53 \\
\hline 5 & $\begin{array}{l}\text { 1,3-Dioxane, } \\
\text { Dimethyl-5-Ethylidene }\end{array}$ & 18,041 & 0,33 \\
\hline 6 & Epoxy-Linalooloxide & 18,143 & 0,22 \\
\hline 7 & Geranyl Acetate & 20,656 & 1,18 \\
\hline 8 & Elemol & 27,509 & 0,22 \\
\hline 9 & Isobornyl Acetate & 27,992 & 0,95 \\
\hline 10 & $\begin{array}{l}\text { 1,6,10-Dodecatrien-3-Ol, } \\
\text { 3,7,11-Trimethyl-, S-(Z) }\end{array}$ & 28,158 & 0,59 \\
\hline 11 & $\begin{array}{l}\text { 11-Octadecenoic Acid, } \\
\text { Methyl Ester (CAS) Methyl } \\
\text { 11-Octadecenoate }\end{array}$ & 37,156 & 0,20 \\
\hline 12 & Geranyl Acetate & 37,326 & 0,36 \\
\hline 13 & Neral & 37,551 & 0,20 \\
\hline 14 & $\begin{array}{l}\text { 2,6-Octadien-1-Ol, } \\
\text { Dimethyl-, (E)- }\end{array}$ & 38,111 & 0,38 \\
\hline 15 & Beta.-Citronellol & 42,634 & 0,21 \\
\hline
\end{tabular}




\section{Analisis Komponen Minyak Atsiri dengan GC-MS}

Tabel 3 menunjukkan hasil analisis GC-MS pada sampel RD451. Pada tabel tersebut terlihat bahwa terdapat satu nilai persentase area yang paling tinggi dibandingkan dengan persentase area lainnya. Persentase area tersebut menunjukkan adanya senyawa Z-citral dengan waktu retensi sebesar 17,916 dan persen area sebesar 59,53\%. Terdapat pula senyawa geranil asetat dan juga geraniol pada waktu retensi 20,656 dan 38,111. Pada penelitian yang dilakukan oleh Hanaa et al. (2012), juga menunjukkan adanya ketiga senyawa tersebut pada hasil GC-MS pada minyak atsiri Cymbopogon citratus [19]. Selain ketiga senyawa tersebut, pada penelitian tersebut juga disebutkan bahwa terdapat senyawa lain yang terkandung pada minyak serai dapur, seperti limonen, linalool, neral, dan geranial [19]. Pada penelitian yang dilakukan oleh Fokom et al. (2019), juga ditemukan adanya senyawa geraniol dan geranil asetat [4].

\section{Kesimpulan}

Penelitian ini bertujuan untuk mengetahui adanya pengaruh waktu ekstraksi (60 menit, 75 menit, dan 90 menit), rasio bahan/pelarut (1:4 g/mL dan 1:5 $\mathrm{g} / \mathrm{mL}$ ), serta daya ekstraksi (500 watt dan 600 watt) terhadap hasil minyak atsiri yang diperoleh dari serai dapur. Metode ekstraksi yang digunakan pada penelitian ini adalah hidrodistilasi dengan bantuan microwave. Berdasarkan hasil analisis, dapat disimpulkan bahwa tidak adanya pengaruh variabel tersebut terhadap densitas minyak atsiri yang dihasilkan. Densitas minyak atsiri yang diperoleh berkisar antara $0,880-0,920 \mathrm{~g} / \mathrm{mL}\left(30^{\circ} \mathrm{C}\right)$. Namun, yield menunjukkan bahwa semakin besar rasio bahan/pelarut maka yield yang dihasilkan semakin besar. Pada penelitian ini, rasio 1:5 g/mL memberikan nilai yield yang lebih besar. Komponen minyak serai dapur yang diperoleh terdiri dari beberapa senyawa, yaitu Z-citral, geranil asetat, dan geraniol.

\section{Ucapan Terima Kasih}

Ucapan terima kasih ditujukan kepada Program Studi Teknik Kimia Fakultas Teknologi Industri Universitas Islam Indonesia yang telah memberikan dukungan berupa pendanaan serta peralatan yang memadai sehingga penelitian ini dapat dilakukan dengan baik.

\section{Daftar Pustaka}

[1] N. Khalil, M. Ashour, S. Fikry, A. N. Singab, and O. Salama, "Chemical composition and antimicrobial activity of the essential oils of selected Apiaceous fruits," Futur. J. Pharm. Sci., vol. 4, no. 1, pp. 88-92, 2018.

[2] F. Nazzaro, F. Fratianni, L. De Martino, R. Coppola, and V. De Feo, "Effect of essential oils on pathogenic bacteria," Pharmaceuticals, vol. 6, no. 12, pp. 14511474, 2013.

[3] S. Mandal and M. Mandal, "Coriander
(Coriandrum sativum L.) essential oil: Chemistry and biological activity," Asian Pac. J. Trop. Biomed., vol. 5, no. 6, pp. 421428, 2015.

[4] R. Fokom et al., "Growth, essential oil content, chemical composition and antioxidant properties of lemongrass as affected by harvest period and arbuscular mycorrhizal fungi in field conditions," Ind. Crops Prod., vol. 138, no. June, p. 111477 , 2019.

[5] F. Benkaci-Ali, A. Baaliouamer, and B. Y. Meklati, "Kinetic study of microwave extraction of essential oil of Nigella sativa L. seeds," Chromatographia, vol. 64, no. 3-4, pp. 227-231, 2006.

[6] H. S. Kusuma and M. Mahfud, "Preliminary study: Kinetics of oil extraction from sandalwood by microwave-assisted hydrodistillation," IOP Conf. Ser. Mater. Sci. Eng., vol. 128, no. 1, 2016.

[7] O. A. Lawal, A. L. Ogundajo, N. O. Avoseh, and I. A. Ogunwande, "Cymbopogon citratus", in Medicinal Spices and Vegetables from Africa. London: Elsevier Inc, 2017, pp. $397-423$.

[8] E. H. Chisowa, D. R. Hall, and D. I. Farman, "Volatile constituents of the essential oil of Cymbopogon citratus Stapf grown in Zambia," Flavour Fragr. J., vol. 13, no. 1, pp. 29-30, 1998.

[9] E. O. Ajayi, A. P. Sadimenko, and A. J. Afolayan, "GC-MS evaluation of Cymbopogon citratus (DC) Stapf oil obtained using modified hydrodistillation and microwave extraction methods," Food Chem., vol. 209, pp. 262-266, 2016.

[10] A. Wany, A. Kumar, S. Nallapeta, S. Jha, V. K. Nigam, and D. M. Pandey, "Extraction and characterization of essential oil components based on geraniol and citronellol from Java citronella (Cymbopogon winterianus Jowitt)," Plant Growth Regul., vol. 73, no. 2, pp. 133145, 2014.

[11] H. S. Kusuma, A. Altway, and M. Mahfud, "Solvent-free microwave extraction of essential oil from dried patchouli (Pogostemon cablin Benth) leaves," J. Ind. Eng. Chem., vol. 58, pp. 343-348, 2018.

[12] M. Chenni, D. El Abed, S. Neggaz, N. Rakotomanomana, X. Fernandez, and F. Chemat, "Solvent free microwave extraction followed by encapsulation of O. basilicum L. essential oil for insecticide purpose," J. Stored Prod. Res., vol. 86, 2020.

[13] C. A. Pramani, "Pengaruh Perlakuan Awal Bahan Baku dan Waktu Destilasi Serai Dapur (Cymbopogon citratus) Terhadap Karakteristik Fisikokimia Minyak Serai 
Dapur (Lemongrass oil)", Skripsi, Univ. Sebelas Maret. Surakarta, 2010.

[14] Y. E. Feriyanto, P. J. Sipahutar, and P. Prihatini, "Menggunakan Metode Distilasi Uap dan Air dengan Pemanasan Microwave," J. Tek. Pomits. vol. 2, no. 1, pp. 93-97, 2013.

[15] T. Liu et al., "Application of ionic liquids based microwave-assisted simultaneous extraction of carnosic acid, rosmarinic acid and essential oil from Rosmarinus officinalis," J. Chromatogr. A, vol. 1218, no. 47, pp. 8480-8489, 2011.

[16] K. P. Solanki, M. A. Desai, and J. K. Parikh, "Microwave intensified extraction: A holistic approach for extraction of citronella oil and phenolic compounds," Chem. Eng. Process. Process Intensif., vol. 146, no. November, 2019.

[17] Z. Drinić, D. Pljevljakušić, J. Živković, D. Bigović, and K. Šavikin, "Microwaveassisted extraction of O. vulgare L. spp. hirtum essential oil: Comparison with conventional hydro-distillation," Food Bioprod. Process., vol. 120, no. 2006, pp. 158-165, 2020.

[18] J. R. Dean, "Microwave extraction," Compr. Sampl. Sample Prep., vol. 2, no. May 1994, pp. 135-149, 2012.

[19] A. R. Mohamed Hanaa, Y. I. Sallam, A. S. ElLeithy, and S. E. Aly, "Lemongrass (Cymbopogon citratus) essential oil as affected by drying methods," Ann. Agric. Sci., vol. 57, no. 2, pp. 113-116, 2012. 